\title{
IMPACT OF LIMITED ORAL ANTITUBERCULOSIS INFORMATION TO THE TUBERCULOSIS PATIENTS' COMPLIANCE AND THEIR QUALITY OF LIFE
}

\author{
Handayani D, Perwitasari DA \\ Fakultas Farmasi Universitas Ahmad Dahlan Yogyakarta \\ Jl. Prof Dr. Supomo, Yogyakarta. Telp. (0274) 379418 \\ Email : diahperwitasari2003@yahoo.com
}

\begin{abstract}
The study about impact of limited oral antituberculosis information delivered by pharmacist to patient compliance and their quality of life in two public health centers in Yogyakarta has been carried out. This study was performed using cohort event monitoring design, with 14 pulmonary TB patients and positive Acid Resistant Basil were treated with oral antituberculosis (OAT) for at least 1 month and were older than 15 years old. We observed the compliance of one group of patients using oral antituberculosis who were serviced with OAT information and the other group without OAT information service. The patients' compliance was checked by counting the remaining $O A T$ and by interviewing the patients, meanwhile patient's quality of life were measured by SF-36 instrument. The correlation between limited OAT information service and patient compliance were analysed using Chi Square and quality of patient's life were analysed using Independent t-Test with 95\% confidence level. It was shown that characteristics of patients such as age, gender, education, duration of illness, and Directly Observed Treatment involvement did not influence patient compliance. There was no significant correlation between limited OAT information service to patient compliance and patients' quality of life $(P>0.05)$. There is no impact of limited OAT information service to the TB patients' compliance and their quality of life. We suggested that the further and deeply information service delivered by pharmacists in the public helath centers in Yogyakarta should be carried out.
\end{abstract}

Key word : drug information service, adherence, quality of life, pulmonary TB

\section{PENDAHULUAN}

Tuberculosis (TB) is still being a significant burden in Indonesia. Among countries in the world, Indonesia is in the third rank of country with TB problem after India (30\%) and China (15\%). The incidence of $\mathrm{TB}$ in Indonesia was 530.000 cases, the prevalence reached 600.000 with 101.000 of mortalities in 2004. According to the national health survey, the completeness of health 
facilities is still being problem in the east part of Indonesia, thus, there will be unreported TB cases (Awusi et al, 2009).

Even the oral antituberculosis (OAT) are affordable in Indonesia, there are other problem related with $\mathrm{TB}$, such as high mortality rate, patients' compliance and adverse drug event. In the 1993, WHO decided that TB is in the emergency situation in the world. It is estimated that there are 7-8 million TB cases and 1.3-1.6 million mortalities every year. In 2010, there were 8.5-9.2 million TB cases and 1.2-1.5 million mortalities of TB and HIV every year (WHO, 2011). The patients' compliance is one of the key for the successful of treatment for TB, besides nutritional status, host immunity, self and environtment hygiene (Muchid, 2005).

OAT must be administered regularly for at least 6 months, with 2 months of intensive phase and 4 months of continuation phase. Failure of TB treatment usually caused by incompliance because of the unaffordable drugs. Thus, we need the critical role of pharmacist in managing of TB drug supply and in monitoring patients' compliance (Muchid, 2005). Drug information service delivered by health proffesionals could increase patients' compliance. The limited human resources in public health centers could be a problem in delivering the drug information service. Patients' compliance is defined as patients' behaviour in using the medicines, following the diet program and changing their life styles (Mahiwa, 2011; Melanie, 2009). Patient's uncompliance involves personal believe in drug effectivity, progress of diseases, psychologic factor and social factor (Muchid, 2005). Tuberculosis can give significant impact to the patients' quality of life. Since this is long duration of treatment, it can cause adverse drug event and may limited patients' daily activities (Guo et al, 2009; Perwitasari et al, 2010). This study is aimed to understand the impact of drug information service delivered by pharmacist to patients' compliance and quality of life.

\section{METHODS}

We used cohort design (cohort event monitoring) with one group patients were delivered by limited OAT information and the other group without OAT information. The limited OAT information which only involved the drug administration were delivered by the pharmacist in two public health centers in Yogyakarta. This service was given to the patients when they take the prescription. We defined the patients' compliance by counting the rest of OAT in the last day of treatment. The patients' quality of life was measured by Indonesian version of Short Formulary -36 (SF-36) questionnaire. The SF-36 questionnaire contains of general health function, physical function, role problem related with the physical function, social function, emotional function, pain, mental function and vitality. The patients' uncompliance risk factors were collected by interview method.

We recruited the TB patients in two public health centers in Yogyakarta for 3 months. These patients with age $=$ 15 were following the TB treatment in the public health centers at least for one month. 
Table I. Patients' characteristics

\begin{tabular}{|l|c|c|}
\hline \multicolumn{1}{|c|}{ Characteristics } & N & \% \\
\hline Age & 10 & 71.4 \\
20-50 yo & 4 & 28.6 \\
\hline 50 yo & & \\
\hline Gender & 6 & 57.1 \\
Male & 8 & 42.9 \\
Female & & \\
\hline Last Education & 13 & 92.9 \\
Elementary, Junior and senior High School & 1 & 7.1 \\
Bachelor & & \\
\hline Duration of tuberculosis & 12 & 85.7 \\
1-3 months & 2 & 14.3 \\
$>$ 3 months & & \\
\hline Directly Observed Treatment (DOT) involvement & 9 & 35.3 \\
With DOT & 5 & \\
Without DOT & & \\
\hline
\end{tabular}

Data was analyzed using Chi square test to understand the correlation between some factors and patients' compliance and correlation between drug information service and patients' compliance. The Independent t-test was carried out to understand the impact of OAT information service and patients' quality of life.

\section{RESULTS AND DISCUSSION}

We recruited 14 TB patients during 3 months in two public health centers in Yogyakarta. The patients' characteristic are listed in Tabel I.

All of the patients received Fixed Dose Combination (FDC) of OAT. Ten patients $(71.4 \%)$ were in $20-50$ yo, 4 patients were female $(42,9 \%)$ and 13 patients passed the high school education (92,9\%). Only 2 patients experienced tuberculosis for more than 3 months. It means these two patients have been gotten used with the OAT longer than the other group.

The chi square analysis showed that the patient characteristics did not have significant influence to the patients' compliance $(\mathrm{P}>0.05)$. This could be caused by limited sample size in this study. However, the drug information service can increase patients' compliance as much as 1.2 times. According to this result, we suggested to the pharmacists in the public health centers, that they should more give awareness in delivering OAT information, not only about how to administer the OAT correctly, but also about the adverse effect, monitoring of adverse effect and how to overcome the adverse effect. These informations will be usefull in increasing patients' 
compliance and the outcome of treatment will support the succesfull of TB treatment. According to the patients' interview, most of the patients suggested that the drug information service should be delivered by the pharmacist only one time during the treatment duration. This suggestion could be caused by the way of pharmacists in delivering the OAT information is not appropriate or the limited information about OAT. Not only about OAT administration, but also the patients need more information about OAT. Furthermore, TB patients need more discussion in private room and more time to understand about the OAT delivery. The may be ashamed because of their disease, if the information is deliveried in common place.
Table II showed the differences of patients' quality of life domains between the group of patients with limited OAT information service and patients without limited OAT information service. It shows that the service of limited OAT information did not give significant impact to the patients' quality of life $(p>0.05)$. This phenomena could be caused by most of te patients were new in TB treatment (less than 3 months). Thus, we still don't know about the impact of $\mathrm{TB}$ or $\mathrm{Tb}$ treatment in longer duration of treatment.

Table III shows that patients' compliance did not have significant effect to the patients' quality of life. There where no significant differences of patients' quality of life domain between comply and incomply patients.

Table II. Patients' quality of life according to limited OAT information service

\begin{tabular}{|c|c|c|c|}
\hline Limited OAT information service & Mean \pm SD & $P$ value & Domain \\
\hline $\begin{array}{l}\text { Yes } \\
\text { No }\end{array}$ & $\begin{array}{l}72.53 \pm 12.15 \\
75.47 \pm 10.39\end{array}$ & 0.635 & General health \\
\hline $\begin{array}{l}\text { Yes } \\
\text { No }\end{array}$ & $\begin{array}{l}95.00 \pm 7.64 \\
89.60 \pm 8.06\end{array}$ & 0.223 & Physical \\
\hline $\begin{array}{l}\text { Yes } \\
\text { No }\end{array}$ & $\begin{array}{l}46.43 \pm 46.61 \\
60.71 \pm 28.35\end{array}$ & 0.502 & Physical role \\
\hline $\begin{array}{l}\text { Yes } \\
\text { No }\end{array}$ & $\begin{array}{l}57.14 \pm 46.00 \\
47.62 \pm 26.22\end{array}$ & 0.643 & Emotional \\
\hline $\begin{array}{l}\text { Yes } \\
\text { No }\end{array}$ & $\begin{array}{l}87.86 \pm 24.47 \\
94.64 \pm 14.17 \\
\end{array}$ & 0.537 & Social \\
\hline $\begin{array}{l}\text { Yes } \\
\text { No }\end{array}$ & $\begin{array}{l}71.78 \pm 22.85 \\
76.43 \pm 21.11\end{array}$ & 0.698 & Pain \\
\hline $\begin{array}{l}\text { Yes } \\
\text { No }\end{array}$ & $\begin{array}{c}89.28 \pm 6.07 \\
81.43 \pm 11.07\end{array}$ & 0.126 & Energy \\
\hline $\begin{array}{l}\text { Yes } \\
\text { No }\end{array}$ & $\begin{array}{l}81.17 \pm 15.64 \\
86.29 \pm 11.04\end{array}$ & 0.539 & Mental role \\
\hline
\end{tabular}


An interesting phenomena is shown in this study which may be support the result of quality of life analysis. The patients' live in area which were far from the public health center, even actually there were more nearest public health center around their home. We suggested that TB patients in this study were more convenient if their disease were not recognized by their neighbour or their family.

\section{CONCLUSION}

There were no significant impact of limited OAT information to the TB patients' compliance and their quality of life. We suggested the intensely information about OAT should be carried out by the pharmacists in public health centers in Yogyakarta.

\section{REFERENCES}

Awusi, Djam'an, Hadiwijoyo, 2009, Faktor-Faktor Yang Mempengaruhi Penemuan Penderita TB Paru Di Kota Palu Provinsi Sulawesi Selatan, Berita Kedokteran Masyarakat 25; 2; 59-68

Guo, Marra, Marra, 2009. Measuring healty-related Quality of Life in Tuberculosis: A Systematic Review, Health Qual Life Outcomes. 2009; 7: 14

Mahiwa, 2011, Standart Operating Procedure Pelayanan Informasi

Table III. Patients' quality of life in according to patients' compliance

\begin{tabular}{|c|c|c|c|}
\hline Patients' compliance & Mean \pm SD & $P$ value & Domain \\
\hline $\begin{array}{l}\text { Comply } \\
\text { Not comply }\end{array}$ & $\begin{array}{l}74.87 \pm 11.32 \\
70.83 \pm 11.02\end{array}$ & 0.593 & General health \\
\hline $\begin{array}{l}\text { Comply } \\
\text { Not comply }\end{array}$ & $\begin{array}{l}92.47 \pm 9.07 \\
91.66 \pm 2.88 \\
\end{array}$ & 0.885 & Physical \\
\hline $\begin{array}{l}\text { Comply } \\
\text { Not comply }\end{array}$ & $\begin{array}{l}47.72 \pm 39.46 \\
75.00 \pm 25.00\end{array}$ & 0.285 & Physical role \\
\hline $\begin{array}{l}\text { Comply } \\
\text { Not comply }\end{array}$ & $\begin{array}{l}51.51 \pm 40.45 \\
55.55 \pm 19.25\end{array}$ & 0.872 & Emotional \\
\hline $\begin{array}{l}\text { Comply } \\
\text { Not comply }\end{array}$ & $\begin{array}{l}88.86 \pm 21.60 \\
100.00 \pm 0.00\end{array}$ & 0.403 & Social \\
\hline $\begin{array}{l}\text { Comply } \\
\text { Not comply }\end{array}$ & $\begin{array}{l}77.27 \pm 20.87 \\
62.50 \pm 21.65\end{array}$ & 0.301 & Pain \\
\hline $\begin{array}{l}\text { Comply } \\
\text { Not comply }\end{array}$ & $\begin{array}{l}83.64 \pm 9.77 \\
91.57 \pm 5.77 \\
\end{array}$ & 0.206 & Energy \\
\hline $\begin{array}{l}\text { Comply } \\
\text { Not comply }\end{array}$ & $\begin{array}{c}82.18 \pm 14.23 \\
90.57 \pm 6.11\end{array}$ & 0.344 & Mental role \\
\hline
\end{tabular}


Obat (PIO),

http://tytutmahiwa.com-html, Di akses tanggal 18 April 2012

Muchid, 2005, Pharmaceutical Care Untuk Penyakit Tuberculosis, Direktorat Bina Farmasi Komunitas Dan Klinik Direktorat Jenderal, Depkes RI

Melanie, 2009, Komunikasi ApotekerPasien Edisi 2, hal 25, Jakarta, EGC

Perwitasari, Atthobari, Dwiprahasto, Hakimi, Gelderblom, Putter, et al,
2010, Translation and Validation of EORTC QLQ-C 30 Into Indonesian Version for Cancer Patients in Indonesia, Japannese Journal of Clinical Oncology, Vol 41; 519-529

WHO, 2011, Global Tuberculosis Control 2011, World Health Organization (WHO/HTM/TB/2011.16) 